Article

\title{
Efficacy of A Poly(MeOEGMA) Brush on the Prevention of Escherichia coli Biofilm Formation and Susceptibility
}

\author{
Patrícia Alves ${ }^{1}{ }^{\circledR}$, Luciana Calheiros Gomes ${ }^{1}\left(\mathbb{D}\right.$, Cesar Rodríguez-Emmenegger ${ }^{2, *}$ and \\ Filipe José Mergulhão ${ }^{1, * \mathbb{D}}$ \\ 1 LEPABE—Laboratory for Process Engineering, Environment, Biotechnology and Energy, \\ Faculty of Engineering, University of Porto, 4200-465 Porto, Portugal; patriciamarialves@gmail.com (P.A.); \\ luciana.gomes@fe.up.pt (L.C.G.) \\ 2 DWI-Leibniz Institute for Interactive Materials and Institute of Technical and Macromolecular Chemistry, \\ RWTH Aachen University, Forckenbeckstraße 50, 52074 Aachen, Germany \\ * $\quad$ Correspondence: rodriguez@dwi.rwth-aachen.de (C.R.-E.); filipem@fe.up.pt (F.J.M.); \\ Tel.: +49-(0)241-80233-62 (C.R.-E.); +351-225-081-668 (F.J.M.)
}

Received: 15 April 2020; Accepted: 27 April 2020; Published: 29 April 2020

\begin{abstract}
Urinary tract infections are one of the most common hospital-acquired infections, and they are often associated with biofilm formation in indwelling medical devices such as catheters and stents. This study aims to investigate the antibiofilm performance of a polymer brush-poly[oligo(ethylene glycol) methyl ether methacrylate], poly(MeOEGMA) — and evaluate its effect on the antimicrobial susceptibility of Escherichia coli biofilms formed on that surface. Biofilms were formed in a parallel plate flow chamber (PPFC) for $24 \mathrm{~h}$ under the hydrodynamic conditions prevailing in urinary catheters and stents and challenged with ampicillin. Results obtained with the brush were compared to those obtained with two control surfaces, polydimethylsiloxane (PDMS) and glass. The polymer brush reduced by $57 \%$ the surface area covered by $E$. coli after $24 \mathrm{~h}$, as well as the number of total adhered cells. The antibiotic treatment potentiated cell death and removal, and the total cell number was reduced by $88 \%$. Biofilms adapted their architecture, and cell morphology changed to a more elongated form during that period. This work suggests that the poly(MeOEGMA) brush has potential to prevent bacterial adhesion in urinary tract devices like ureteral stents and catheters, as well as in eradicating biofilms developed in these biomedical devices.
\end{abstract}

Keywords: polymer brush; Escherichia coli; biofilm formation; antifouling properties; antibiotic susceptibility

\section{Introduction}

Bacterial biofilms are a severe problem in the pathogenesis of biomaterial-associated infections (BAI), leading to significant patient morbidity and mortality, and high costs to health services $[1,2]$. Over the past century, the use of medical devices, such as catheters, prosthetic joints, stents, artificial heart valves, pacemakers and other implants, has increased dramatically, which may result in BAI $[3,4]$. According to the American National Institutes of Health, the development and persistence of biofilms are responsible for $75 \%$ of all human bacterial infections [1]. Catheter-associated urinary tract infection (CAUTI) is one of the most common hospital-acquired infections [5,6] where Escherichia coli plays a key role due to its ability to adhere to biomaterials [7-10]. E. coli has also shown to persist and regrow after antibiotic exposure due to many factors, including reduced penetration of antibiotics in biofilms and/or cellular extrusion of drugs [7]. This may be due to the fact that biofilm cells produce a complex polymeric matrix, which protects the biofilm from antibiotic penetration and whose structure 
is strongly influenced by the substratum on which the biofilm forms $[11,12]$ and by the bulk liquid phase which flows over the biofilm $[13,14]$.

The high resistance of biofilms to conventional antibiotic therapy has driven research into the development of novel surfaces to decrease the attachment of microorganisms and consequent biofilm formation $[15,16]$. Polymer brushes have been developed to prevent the adsorption of biomolecules and the adhesion process by limiting the contact of substratum with living bacteria [17-19], which is particularly relevant in biomedical applications [20-22]. Furthermore, several polymer brushes based on 2-hydroxyethyl methacrylate (HEMA), oligo(ethylene glycol), 2-hydroxyethyl acrylamide (HEAA) [23], oxazolines [24], carboxybetaines, and $\mathrm{N}$-(2-hydroxypropyl) methacrylamide (HPMA), including the one tested in this work (poly[oligo(ethylene glycol) methyl ether methacrylate], poly(MeOEGMA)), were shown to be resistant to the adsorption of compounds from human biological fluids such as blood plasma, urine, cerebrospinal fluid and saliva, as well as different cell lines and bacteria [17,20,25-28]. Moreover, a study using single-cell force spectroscopy demonstrated that antifouling polymer brushes can reduce the forces involved in bacterial attachment [29]. For instance, the force needed to detach Yersinia pseudotuberculosis was reduced over three orders of magnitude when comparing to Teflon or glass [29].

Besides the surface properties, the complex process of biofilm formation depends on multiple factors such as hydrodynamics and nutrient availability [30,31]. Several platforms for biofilm studies have been developed over the past decades [32]. Parallel plate flow cells (PPFCs) have been used for the study of biofilm formation under environmentally relevant hydrodynamic conditions, enabling a better understanding of the factors affecting the initial bacterial adhesion, which is the onset of biofilm development, as well as the online monitoring of biofilm development $[14,33,34]$. In recent work using a PPFC, two polymer brushes with well-known antifouling properties-poly(MeOEGMA) and poly(HPMA)-reduced the adhesion of E. coli after $30 \mathrm{~min}$ over a relevant range of shear stresses ( 0.005 to $0.056 \mathrm{~Pa})$, including the one reported for urinary catheters (shear rate of $15 / \mathrm{s}$ ) [22]. Shear stress values within this range are also found in some problematic areas of ureteric stents that are prone to bacterial accumulation and encrustation $[35,36]$. These polymer brushes also shown to be resistant to the adsorption of macromolecules from urine and serum, being promising surfaces to delay cell attachment in biomedical devices [22]. However, the mentioned investigation was performed using citrate buffer as a liquid medium to enable a more accurate thermodynamic analysis of the initial adhesion process. For these reasons, it is important to perform biofilm formation assays using a suitable medium that mimics the environment of interest since the fluid composition affects the behavior of pathogens involved in clinical infections [37,38]. Although many studies were performed aiming to better understand the bacterial attachment to different surfaces, few consider the importance of shear flow in bacteria-surface interactions $[13,14,21,39,40]$.

The purpose of this work was to evaluate the antifouling performance of the poly(MeOEGMA) brush on E. coli biofilm formation and antimicrobial susceptibility. This polymer brush was selected due to its resistance to protein adsorption and bacterial adhesion (up to $90 \%$ when compared to glass) [22]. A well-described PPFC system [14] was used where synthetic urine was flown to mimic the shear rate typically found in urinary catheters and ureteric stents. The effect of the polymer brush on biofilm architecture was analyzed and compared with two control surfaces, polydimethylsiloxane (PDMS; a material commonly used for urinary catheters manufacture) and glass (surface used as a standard reference for adhesion studies). This work suggests that the poly(MeOEGMA) brush has the potential to reduce infections in urinary tract devices with high efficiency by reducing the biofilm growth and by making the biofilms formed in these biomedical devices more susceptible to the current antibiotic therapies.

\section{Results}

E. coli biofilm distribution on PDMS, bare glass and poly(MeOEGMA) brush was observed in real-time in the PPFC under hydrodynamic conditions similar to those found in urinary catheters and 
stents. The area fraction covered by the biofilm was chosen as a representative measure of adhesion during biofilm growth $(0.5,2$ and $24 \mathrm{~h})$ and antibiotic treatment for an additional $8 \mathrm{~h}$ period (32 h) (Figure 1). Lower surface coverages were registered on the polymer brush when compared to PDMS and glass surfaces for all time points $(p<0.01)$. After $24 \mathrm{~h}$, in the polymer brush, the surface coverage decreased by $60 \%$ on average compared to PDMS and glass ( $p<0.0001)$. Regarding the ampicillin treatment, the biofilm-covered area increased slightly during the $8 \mathrm{~h}$ of exposure (Figure 1 ). It can be noted that for the PDMS the increase of the area fraction covered by E. coli was about $46 \%$, while for glass and the polymer brush surfaces, the increase reached $15 \%$ and $31 \%$, respectively. Nevertheless, it is important to note that, even after the antimicrobial treatment, the poly(MeOEGMA) brush was the most effective surface in reducing cell adhesion, with 50\% and 65\% fewer cells than PDMS and glass, respectively $(p<0.0001)$.

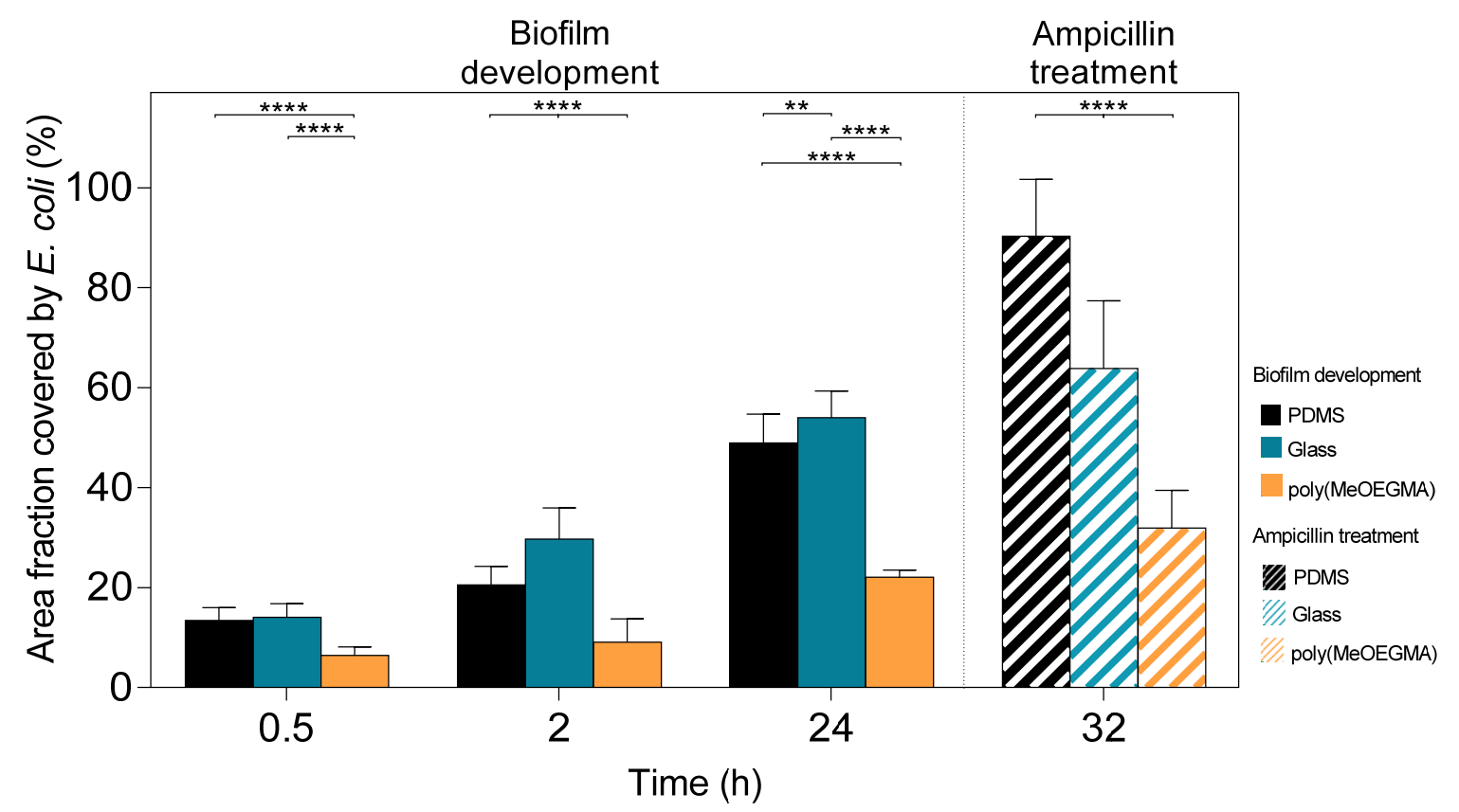

Figure 1. Surface area fraction covered during biofilm development (up to $24 \mathrm{~h}$ ) and ampicillin treatment for an additional $8 \mathrm{~h}$ period $(32 \mathrm{~h}$ ) on polydimethylsiloxane (PDMS) ( $\mathbf{\square}$ and $\mathbb{N}$, respectively), glass ( $\mathbf{a}$ and $\%$, respectively), and poly(MeOEGMA) brush ( $\mathbf{\square}$ and $\%$, respectively). Standard deviations for three independent samples are presented. Statistical significance for all the surfaces at each time point was determined by one-way ANOVA followed by Tukey's multiple-comparison test (**** for $p<0.0001$, and ${ }^{* *}$ for $\left.p<0.01\right)$.

Figure 2 shows the number of total, viable and culturable cells on the tested surfaces before and after ampicillin exposure. The total (Figure 2A) and viable cell counts (Figure 2B) were determined by epifluorescence microscopy, whereas the biofilm culturable cells (Figure 2C) correspond to those that form colonies on agar-based media. Before treatment, PDMS had a higher number of total cells compared to glass and polymer brush (42\% and 57\% more cells, respectively; $p<0.0001$, Figure 2A). The antibiotic treatment reduced the total cell amount on PDMS (43\%) and glass (30\%), but the most significant reduction was observed in the polymer brush $(88 \% ; p<0.0001$, Figure 2A). Even before the ampicillin treatment, the biofilm viability (i.e., the number of viable cells divided by the number of total cells) was $87 \%$ on average for the control surfaces and $52 \%$ for the polymer brush. The number of culturable cells (Figure 2C) was lower on glass and on the poly(MeOEGMA) brush when compared to PDMS surface, before and after antibiotic treatment $(p<0.0001$, Figure $2 \mathrm{C})$. Furthermore, the reduction of culturable cells after ampicillin treatment was about $28 \%$ on PDMS, $42 \%$ on glass and $71 \%$ on the polymer brush. 
(A) Total cells (B) Viable cells (C) Culturable cells

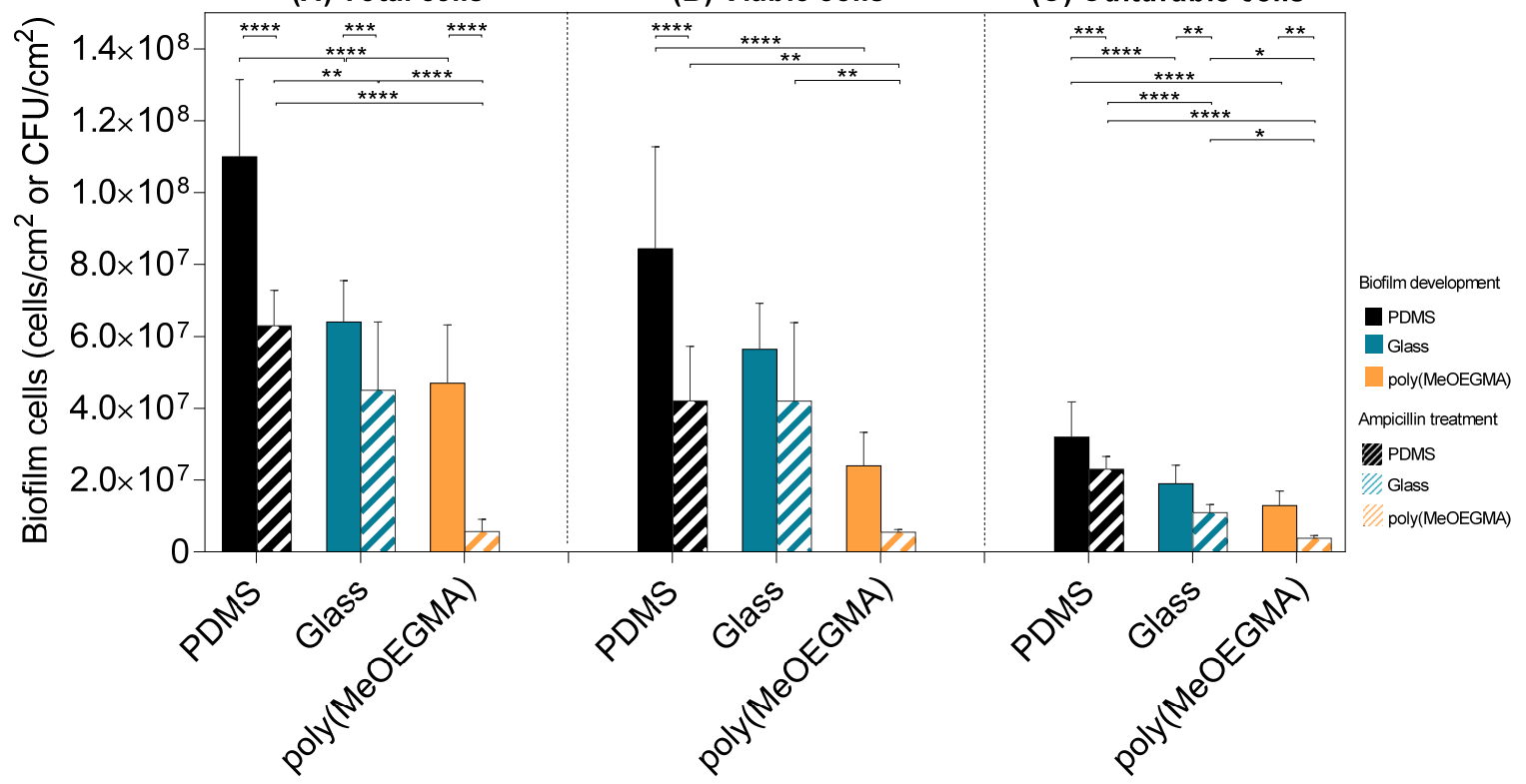

Surface material

Figure 2. Number of (A) total, (B) viable, and (C) culturable cells after $24 \mathrm{~h}$ of biofilm development and after the ampicillin treatment on PDMS ( $\mathbf{\square}$ and $\mathbb{N}$, respectively), glass ( $\mathbf{\square}$ and $\%$, respectively), and poly(MeOEGMA) brush ( $\boldsymbol{\square}$ and $\%$, respectively). Standard deviations for three independent samples are presented. Statistical significance was determined by one-way ANOVA followed by Tukey's multiple-comparison test (**** for $p<0.0001{ }^{* * *}$ for $p<0.001,{ }^{* *}$ for $p<0.01$ and ${ }^{*}$ for $p<0.05$ ).

Optical coherence tomography (OCT) was the imaging technique selected to analyze the spatial distribution of biofilms developed on the surfaces and determine their thickness before and after antibiotic treatment (Figure 3). The two-dimensional (2D)-cross-sectional scans (Figure 3A) show the biofilm mass over the surface material represented by the white line. Figure 3B presents the average biofilm thickness values determined from the acquired $2 \mathrm{D}$ scans. The OCT cross-sectional views confirmed that after $24 \mathrm{~h}$ of biofilm development, the polymer brush showed a lower amount of biofilm compared to PDMS and glass (Figure 3A). Additionally, the representative OCT image of the biofilm formed on the polymer brush showed that this surface had less biofilm than the remaining surfaces, as previously revealed by brightfield microscopy (Figure 1). It is possible to conclude from Figure 3B that, prior to the ampicillin treatment, the biofilm formed on the poly(MeOEGMA) brush was thinner than those formed on PDMS and glass (61\% and 40\% thinner, respectively; $p<0.0001)$. However, after the antibiotic treatment, an increase in the biofilm amount was observed in all surfaces (Figure 3A) and higher thickness values were obtained compared to pre-treatment (11\% higher for PDMS, 21\% for glass and $62 \%$ for the polymer brush; $p<0.05$, Figure 3B). The biofilm formed on the polymer brush seems to have suffered structural changes during the antibiotic treatment, acquiring the form of cell aggregates, which may have increased the biofilm thickness. 

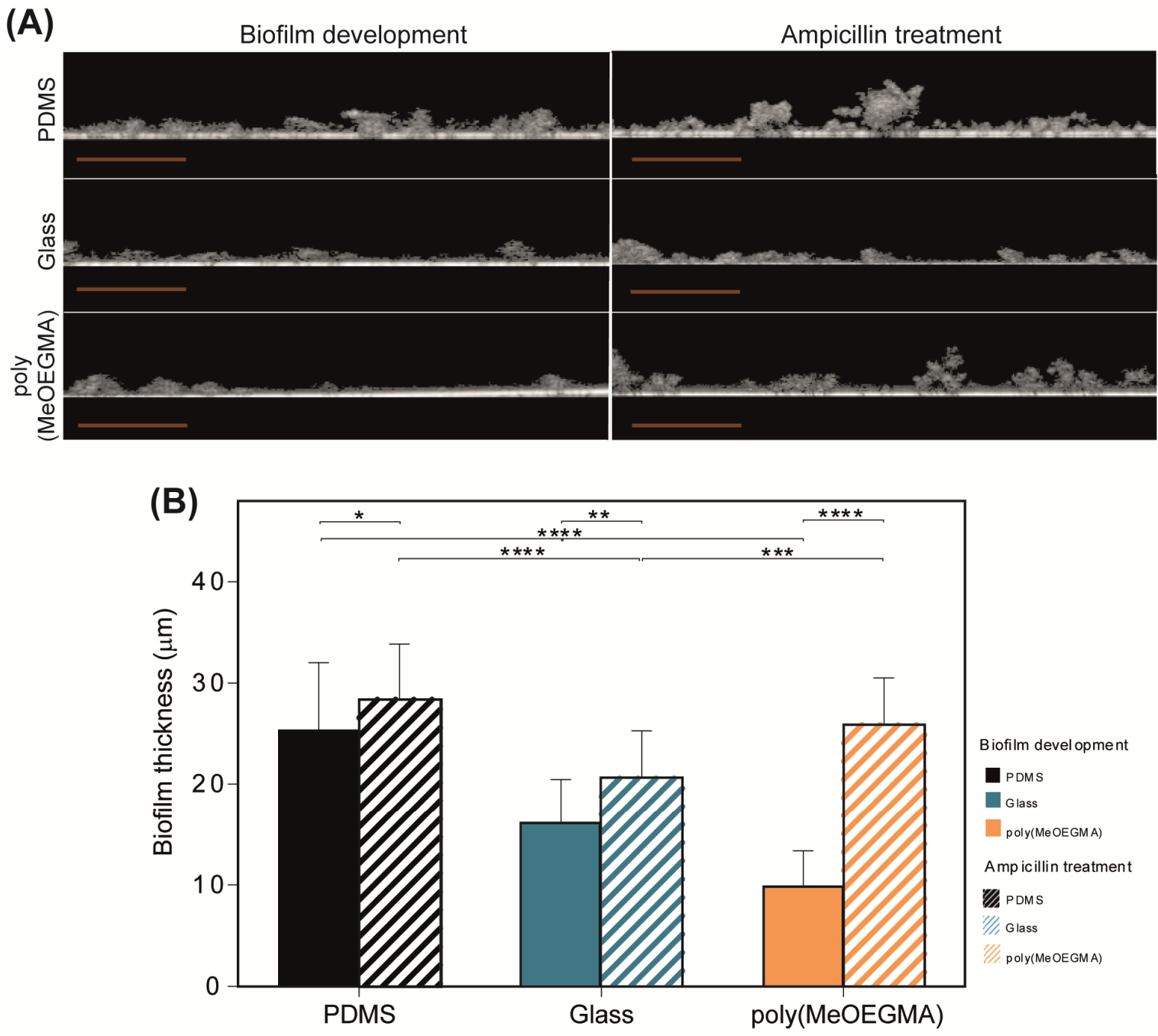

Surface material

Figure 3. OCT analysis of biofilms formed on PDMS, glass and poly(MeOEGMA) brush: (A) representative 2D-cross-sectional views of biofilm structures (orange scale bars correspond to $200 \mu \mathrm{m}$ ), and (B) biofilm thickness after biofilm development and ampicillin treatment on PDMS ( $\mathbf{\square}$ and $\mathbb{N}$, respectively), glass ( $\mathbf{\square}$ and $\%$, respectively) and poly(MeOEGMA) brush ( $\mathbf{\square}$ and $\%$, respectively). Standard deviations obtained from three replicates of each sample are represented. Statistical significance was determined by one-way ANOVA followed by Tukey's multiple-comparison test (**** for $p<0.0001$, *** for $p<0.001, * *$ for $p<0.01$, and * for $p<0.05)$.

SEM images showed that after biofilm growth, the number of adhered cells was higher on PDMS and glass than on the polymer brush (Figure 4A), which corroborates the quantification performed by epifluorescence microscopy (Figure 2A). Concerning the biofilms obtained after antibiotic exposure, higher surface coverages were observed on all tested surfaces (Figure 4A), particularly on the polymer brush, where some cell clusters were also visible, which supports the results obtained by brightfield microscopy (Figure 1) and OCT (Figure 3A). From SEM micrographs, it was also possible to determine the size distribution of biofilm cells on the three surfaces (Figure 4B). An average cell length of $1.5 \mu \mathrm{m}$ was obtained for untreated biofilms, regardless of the surface material. However, after ampicillin exposure, the sessile cells on the polymer brush had an elongated morphology when compared to glass (on average 29\% longer) and PDMS (on average $46 \%$ longer). Indeed, the $E$. coli cells that adhered to poly(MeOEGMA) brush were between 2.1 and $6.1 \mu \mathrm{m}$ (57\% longer than the poly(MeOEGMA) untreated cells), while the cells adhered to glass measured between 1.5 and $4.2 \mu \mathrm{m}$ ( $30 \%$ longer than 
untreated cells obtained from glass) and the cells adhered to PDMS measured between 0.7 and $4.9 \mu \mathrm{m}$ (17\% longer than untreated cells obtained from PDMS).
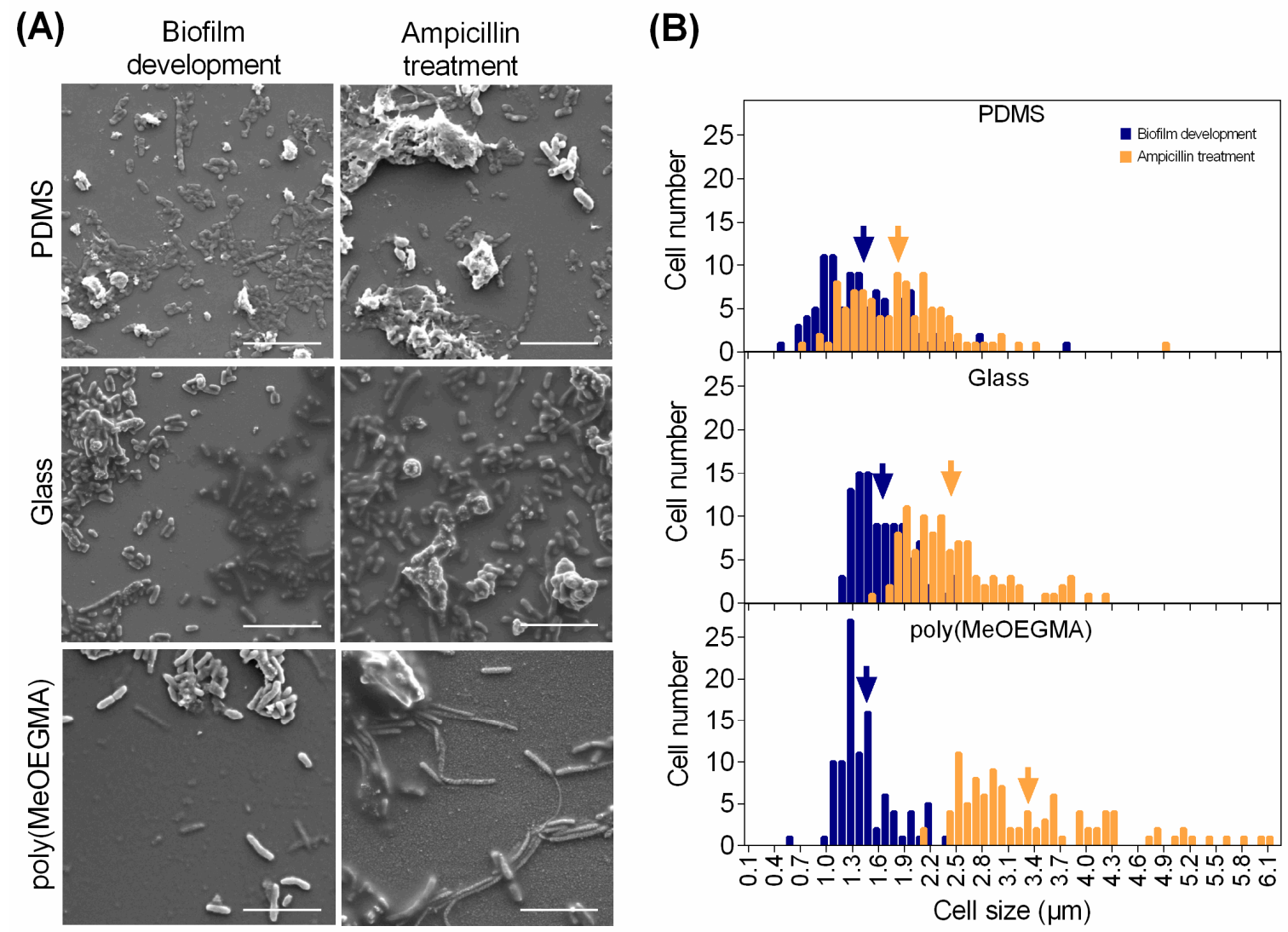

Figure 4. SEM analysis of biofilms formed after $24 \mathrm{~h}$ of development and after the ampicillin treatment on PDMS, glass and poly(MeOEGMA) brush: (A) representative micrographs (magnification: 5000x; bars $=10 \mu \mathrm{m})$; (B) cell size distribution of biofilms before ( $\mathbf{\square})$ and after ampicillin exposure ( $\mathbf{\square})$. The arrows represent the average cell length determined from SEM micrographs for each experimental condition.

\section{Discussion}

Several strategies have been developed to decrease bacterial adhesion and consequent biofilm formation on medical devices, including antiadhesive chemical surface modifications. The main goal of the current study was to evaluate the performance of the poly(MeOEGMA) brush on E. coli biofilm development and antibiotic susceptibility under flow conditions similar to those found in urinary catheters and ureteral stents where this bacterium has a significant impact. Biofilm development was followed for $24 \mathrm{~h}$ to more closely mimic a bladder infection with the continuous supply of bacteria. The biofilm growth was then monitored for an additional $8 \mathrm{~h}$ period where ampicillin was flown on the PPFC system to simulate the infection treatment with one of the most prescribed antibiotics for CAUTIs [41].

E. coli adhered more to PDMS and glass surfaces than to poly(MeOEGMA) after $24 \mathrm{~h}$ of biofilm development, revealing for the first time the long-term antifouling behavior of this polymer brush under urinary flow conditions. Resistance to fouling was expected from coatings with dense grafts, such as the poly(MeOEGMA) brush, which presents long polymer chains that are capable to minimize long-range interactions by creating an effective steric barrier which prevents the adhesion of macromolecules and cells to the surface [42,43]. Indeed, according to the extended Derjaguin-Landau-Verwey-Overbeek (DLVO) theory, attractive long-range interactions are reduced by introducing a water barrier with zero net charge and steric impediment in order to keep bacteria away from the surface [29]. The high 
wettability of the polymer brushes gives rise to an enthalpic barrier as water molecules have to be removed for proteins or bacteria to foul the surface [44]. Previous work from our research group [22] reported the strong antiadhesive effect of the polymer brush, with a reduction of $90 \%$ of cell adhesion in the first $30 \mathrm{~min}$ when citrate buffer was used as culture medium under the same hydrodynamic conditions. In the current work, synthetic urine medium was used to mimic the physiological conditions of the urinary system. An increase in adhesion on the polymer brush surface was evident when in contact with synthetic urine. This is probably related to the use of a high nutrient medium that may have formed a conditioning film, promoting bacterial adhesion $[20,45]$. Surface plasma resonance showed the resistance of the poly(MeOEGMA) brush to the adsorption of proteins or other macromolecules present in human urine [22]. After $15 \mathrm{~min}$, a wavelength shift of less than $15 \mathrm{ng} / \mathrm{cm}^{2}$ was observed and upon $2 \mathrm{~h}$ of contact with urine, the fouling corresponded to less than $5 \%$ of the surface saturation [22]. This suggests that the antifouling properties of the polymer brush under the specific conditions of this work were probably surpassed by the intrinsic characteristics of $E$. coli, a motile organism containing bacterial appendages which may facilitate adhesion [46,47]. Concerning the susceptibility assays, the antibiotic ampicillin was able to remove cells from the biofilms on all of the tested surfaces, and the removal was higher with the polymer brush. The same effect of ampicillin was previously observed in 24-h E. coli biofilms formed on glass [48] where more than $50 \%$ of the sessile cells were removed after only $3 \mathrm{~h}$ of antibiotic exposure. The higher cell detachment from the polymer brush may be related to its weaker interaction with the bacterium [29,49]. According to Rodríguez-Emmenegger et al. [29], the work necessary to detach Y. pseudotuberculosis (a Gram-negative bacterium as E. coli) from brushes such as poly(MeOEGMA) and poly(HPMA) was between $2 \%$ and $20 \%$ of the work employed on glass. Besides its effect on cell removal, the antibiotic circulating into the PPFC system also promoted a higher reduction in the number of culturable cells of poly(MeOEGMA) brush compared to PDMS and glass surfaces.

The OCT images obtained after antibiotic treatment revealed that the biofilm cells adhered to the polymer brush experienced spatial reorganization, giving rise to aggregates that may be responsible for increasing the biofilm thickness. SEM analysis revealed that ampicillin-treated cells were more elongated than the untreated cells on all tested surfaces and formed cell clusters on the polymer brush. In addition, the elongation phenomenon was more noticeable on the brush, indicating a higher effect of the antibiotic treatment on biofilm cells. Previous studies have shown that E. coli cells in contact with ampicillin, a $\beta$-lactam antibiotic which acts to inhibit cell wall synthesis, may suffer morphological changes and spatial rearrangement $[12,48,50,51]$. These alterations may occur in four stages, including elongation, bulge formation, bulge stagnation and lysis [50]. The cluster formation and consequent increase in the biofilm thickness may be due to the overproduction of extracellular polymeric substances (EPS) in response to the osmotic stress resulting from cell-antibiotic interactions. Ionescu and Belkin [52] studied the rpoS function on E. coli strains and their findings suggest that the stress resistance is influenced by the presence of specific genes responsible for the EPS production. It has been reported that rpoS plays a major role in the osmotic stress response of $E$. coli by activating the transcription of a high number of genes that provide osmo- and cross-protection against different stress factors [53,54]. For Enterococcus faecalis (a bacterium responsible for CAUTIs as E. coli and typically susceptible to ampicillin), the formation of a complex 3D-biofilm structure in presence of antibiotics was also associated with a stress response of enterococcal biofilm cells, which promoted a rapid reorganization of biofilm into highly structured microcolonies [55]. A recent work evaluated the effects of ampicillin on surface modifications of four multidrug-resistant $E$. coli strains and concluded that three of them suffered cell elongation, an increase in roughness and nanoscale adhesion forces, became more hydrophilic and increased biofilm formation [56].

Overall, our results show that this polymer brush has potential advantages in the prevention of E. coli adhesion and biofilm formation in urinary tract devices, enabling a more effective eradication of biofilms when combined with antibiotic treatment, thus reducing the risk of recurrent infections. 


\section{Materials and Methods}

\subsection{Test Organism and Culture Conditions}

E. coli JM109(DE3) from Promega (Madison, WI, USA) was selected for its good biofilm-forming capacity in the same platform [14,22,49] and similar biofilm-forming capacity to different E. coli clinical isolates [40]. An overnight culture was prepared by inoculating $500 \mu \mathrm{L}$ of a glycerol stock (kept at $-80{ }^{\circ} \mathrm{C}$ ) in a total volume of $0.2 \mathrm{~L}$ of synthetic urine medium. The medium was prepared as previously described [57] using the following formulation for $1 \mathrm{~L}$ of distilled water: peptone $1 \mathrm{~g}$, yeast extract $0.05 \mathrm{~g}$, lactic acid $1.1 \mathrm{mmol} / \mathrm{L}$, citric acid $0.4 \mathrm{~g}$, sodium bicarbonate $2.1 \mathrm{~g}$, urea $10 \mathrm{~g}$, uric acid $0.07 \mathrm{~g}$, creatinine $0.8 \mathrm{~g}$, calcium chloride. $2 \mathrm{H}_{2} \mathrm{O} 0.37 \mathrm{~g}$, sodium chloride $5.2 \mathrm{~g}$, iron II sulphate. $7 \mathrm{H}_{2} \mathrm{O} 0.0012 \mathrm{~g}$, magnesium sulphate. $7 \mathrm{H}_{2} \mathrm{O} 0.49 \mathrm{~g}$, sodium sulphate. $10 \mathrm{H}_{2} \mathrm{O} 3.2 \mathrm{~g}$, potassium dihydrogen phosphate $0.95 \mathrm{~g}$, di-potassium hydrogen phosphate $1.2 \mathrm{~g}$ and ammonium chloride $1.3 \mathrm{~g}$. The $\mathrm{pH}$ of the solution was then adjusted to 6.5. All media components were purchased from Merck (Germany). The culture was grown on a $1 \mathrm{~L}$ shake-flask at $37^{\circ} \mathrm{C}$ for $15-17 \mathrm{~h}$ with orbital agitation (160 rpm; IKA KS 130 basic, Staufen, Germany). Cells were harvested by centrifugation for $10 \mathrm{~min}$ at $3202 \times g$. The suspension was then adjusted with synthetic urine medium to have an optical density at $610 \mathrm{~nm}$ of 0.1 , equivalent to a cell density of $7.6 \times 10^{7}$ cells $/ \mathrm{mL}$.

\subsection{Surface Preparation}

Bare glass microscope slides (VWR, Portugal) and polydimethylsiloxane (PDMS) (Sylgard 184, Dow Corning, USA) were used as control surfaces. Glass was the substrate where the poly(MeOEGMA) brushes were grafted as in the previous studies addressing bacterial adhesion [22]. Glass was selected due to its transparency, which facilitates microscopy. PDMS is one of the most widely used polymers in the fabrication of medical implants for the urinary tract [58]. PDMS was prepared as previously described [14] and the poly(MeOEGMA) brushes were prepared according to Lopez-Mila et al. [22]. After preparation, round coupons of the poly(MeOEGMA) brush, PDMS and glass were sterilized by spraying with absolute ethanol (100\%; Merck, Germany) for $5 \mathrm{~min}$. Then, they were left to air-dry inside the laminar flow chamber and fixed to the bottom plate of the PPFC [22].

\subsection{Biofilm Assays}

The bacterial suspension was recirculated through the PPFC system at $2 \mathrm{~mL} / \mathrm{s}$, which corresponds to the shear rate of $15 / \mathrm{s}$ found in urinary catheters [59]. As determined by computational fluid dynamics (CFD), the corresponding shear stress was $0.01 \mathrm{~Pa}$ [14] and previous studies revealed that this shear stress value can also be found in some problematic sites of ureteral stents that are prone to bacterial accumulation and encrustation [35,36]. Biofilm development at $37^{\circ} \mathrm{C}$ was monitored in real-time with microscopic images acquired using the Nikon Eclipse LV100 microscope connected to a camera (Nikon digital sight DS-Ri 1, Japan) at different time points $(0.5,2$ and $24 \mathrm{~h})$. As it has been reported that $E$. coli biofilms in urinary catheters are completely mature in $24 \mathrm{~h}$ [7], after that period the $E$. coli suspension was removed from the system and pre-warmed, sterile, synthetic urine to a concentration equivalent to $5 \times \mathrm{MBIC}$ (minimal biofilm inhibitory concentration) of ampicillin (250 $\mu \mathrm{g} / \mathrm{mL}$, diluted in synthetic urine) [48] was flown on the system for $8 \mathrm{~h}$ at the same shear rate. Ampicillin (AppliChem, Germany) was used in the present work since it is an antibiotic commonly prescribed to treat CAUTIs [41]. Brightfield microscopy images were also acquired after the ampicillin treatment (the $32 \mathrm{~h}$ time point). The percentage of surface area covered by E. coli cells was calculated with the ImageJ software (version 1.38e; National Institutes of Health, EUA) for the 0.5, 2, 24 and $32 \mathrm{~h}$ time points as previously described [49].

\subsection{Offline Quantification of Biofilm Cells}

Biofilms were developed for $24 \mathrm{~h}$ and at the end of each experiment the system was rinsed with synthetic urine to remove loosely attached cells. The flow cell was opened and the biofilm from each 
coupon was detached through the swabbing method [60,61] and a biofilm cell suspension diluted in $0.85 \% \mathrm{NaCl}$ was obtained. To assess biofilm culturability (colony forming units, $\mathrm{CFU}$ ), the biofilm suspension was properly diluted and spread on plate count agar (PCA, Oxoid, England). Colony enumeration was carried out after overnight incubation at $37^{\circ} \mathrm{C}$ and the final values were expressed as $\mathrm{CFU} / \mathrm{cm}^{2}$. The adhered cells were stained with 4'-6-diamidino-2-phenylindole (DAPI), which stains both viable and nonviable cells [48]. The viability of biofilm cells was determined with the Live/Dead ${ }^{\circledR}$ (L/D) BacLight ${ }^{\mathrm{TM}}$ Bacterial Viability kit (Invitrogen Life Technologies, Alfagene, Portugal) as previously indicated [48]. All the samples were examined before (the $24 \mathrm{~h}$ time point) and after antibiotic exposure (the $32 \mathrm{~h}$ time point), in which a minimum of 20 fields of view of each stained sample was analyzed using the ImageJ software to estimate the total and viable cell numbers (expressed as cells $/ \mathrm{cm}^{2}$ ).

\subsection{Optical Coherence Tomography (OCT)}

In situ images of the biofilm structure were obtained with a Spectral Domain Optical Coherence Tomography (SD-OCT) system (Thorlabs GmbH, Dachau, Germany) with a central wavelength of $930 \mathrm{~nm}$. The refractive index was set to 1.40 , close to the refractive index of water (1.33), since water is the major component of biofilms [62]. Two-dimensional (2D) images were acquired after $24 \mathrm{~h}$ of biofilm formation and after the ampicillin treatment (the $32 \mathrm{~h}$ time point). The biofilm thickness profiles were determined in at least five images corresponding to different locations for each surface at different time points. For each image, a minimum of 25 points was analyzed using the Thorlabs software tool.

\subsection{Scanning Electron Microscopy (SEM)}

The morphology of E. coli biofilms formed after $24 \mathrm{~h}$ and after exposure to ampicillin was analyzed by SEM. Coupons were removed from the PPFC and gradually dehydrated with ethanol at different concentrations $(10,25,40,50,70,80,90$ and 100\% v/v) [63]. The samples were then air-dried and sputter-coated with a palladium-gold thin film [12]. The biofilms were observed with an SEM/EDS system (FEI Quanta 400FEG ESEM/EDAX Genesis X4M, FEI Company, USA) in high-vacuum mode at $15 \mathrm{kV}$. Cell length was determined for each condition as described by Gomes and Mergulhão [12].

\subsection{Statistical Analysis}

Experiments were carried out in triplicate using different E. coli overnight cultures. Graph production and statistical analysis were performed using GraphPad Prism 6.01 (La Jolla, USA). Data were presented as mean \pm standard deviations. Statistical differences between the polymer brush and the control surfaces (PDMS and glass) were determined using one-way analysis of variance (ANOVA) followed by Tukey's multiple-comparison test.

\section{Conclusions}

Biofilms causing CAUTIs resist antibiotic treatment and often require replacement of infected devices. Current strategies for developing infection-resistant biomaterials have gone through making them non-fouling, bactericidal or both. However, there are few studies that evaluate these new materials in conditions that mimic the real environment where they will be applied. In this study, special attention was paid to hydrodynamic and nutrient conditions since we believe these are critical parameters in translating research into practical applications. The antifouling performance that the poly(MeOEGMA) brush demonstrated in a previous work with citrate buffer was maintained here for a longer period of time. The ability of the polymer brush to significantly delay E. coli biofilm formation when compared to PDMS (a material commonly used in the manufacture of medical settings) makes it a very promising surface to prevent infections in urinary tract devices like urinary catheters and ureteral stents. This study also suggests that the further grafting of active antimicrobial agents such as antibiotics onto the surface of poly(MeOEGMA) brush may favor the detachment of pre-formed biofilms due to the weakly adhering cells on the polymer brush. 
Author Contributions: Conceptualization, P.A., C.R.-E. and F.J.M.; methodology, P.A., C.R.-E. and F.J.M.; investigation, P.A., L.C.G., and F.J.M.; resources, C.R.-E. and F.J.M.; data curation, P.A. and L.C.G.; writing-original draft preparation, P.A., L.C.G. and F.J.M.; supervision, C.R.-E. and F.J.M.; funding acquisition, C.R.-E. and F.J.M. All authors have read and agreed to the published version of the manuscript.

Funding: This research was funded by the Deutsche Forschungsgemeinschaft (DFG, German Research Foundation) via Schwerpunktprogramm "Auf dem Weg zur implantierbaren Lunge" (SPP 2014) with project number 346972946 and by Base Funding-UIDB/00511/2020 of the Laboratory for Process Engineering, Environment, Biotechnology and Energy_LEPABE_funded by national funds through the FCT/MCTES (PIDDAC). P.A. acknowledges the receipt of a Ph.D. grant from the Portuguese Foundation for Science and Technology (FCT) (PD/BD/114317/2016). L.C.G. thanks the Portuguese Foundation for Science and Technology (FCT) for the financial support of her work contract through the Scientific Employment Stimulus_-Individual Call_-[CEECIND/01700/2017]. The authors would like to acknowledge the support from the EU COST Actions ENIUS (CA16217) and ENBA (CA15216). C.R.-E. additionally thanks the support of the research association of Forschungskuratorium Textil e.V. supported via AiF ("Arbeitsgemeinschaft Industrielle Forschungsvereinigungen Otto von Guericke e.V."), research project IGF-No. $19893 \mathrm{~N}$ within the promotion program of "Industrielle Gemeinschaftsforschung" (IGF) of the Federal Ministry for Economic Affairs and Energy on the basis of a decision by the German Bundestag.

Conflicts of Interest: The authors declare no conflict of interest.

\section{References}

1. Miquel, S.; Lagrafeuille, R.; Souweine, B.; Forestier, C. Anti-biofilm activity as a health issue. Front. Microbiol. 2016, 7, 592. [CrossRef] [PubMed]

2. Bjarnsholt, T. The role of bacterial biofilms in chronic infections. APMIS 2013, 121, 1-58. [CrossRef] [PubMed]

3. Lo, E.; Nicolle, L.E.; Coffin, S.E.; Gould, C.; Maragakis, L.L.; Meddings, J.; Pegues, D.A.; Pettis, A.M.; Saint, S.; Yokoe, D.S. Strategies to prevent catheter-associated urinary tract infections in acute care hospitals: 2014 update. Infect. Control Hosp. Epidemiol. 2014, 35, 464-479. [CrossRef] [PubMed]

4. Hancock, V.; Ferrières, L.; Klemm, P. Biofilm formation by asymptomatic and virulent urinary tract infectious Escherichia coli strains. FEMS Microbiol. Lett. 2006, 267, 30-37. [CrossRef] [PubMed]

5. Flores-Mireles, A.L.; Walker, J.N.; Caparon, M.; Hultgren, S.J. Urinary tract infections: Epidemiology, mechanisms of infection and treatment options. Nat. Rev. Microbiol. 2015, 13, 269-284. [CrossRef]

6. Umscheid, C.A.; Mitchell, M.D.; Doshi, J.A.; Agarwal, R.; Williams, K.; Brennan, P.J. Estimating the proportion of healthcare-associated infections that are reasonably preventable and the related mortality and costs. Infect. Control Hosp. Epidemiol. 2011, 32, 101-114. [CrossRef]

7. Koseoglu, H.; Aslan, G.; Esen, N.; Sen, B.H.; Coban, H. Ultrastructural stages of biofilm development of Escherichia coli on urethral catheters and effects of antibiotics on biofilm formation. Urology 2006, 68, 942-946. [CrossRef]

8. Shunmugaperumal, T. Biofilm Eradication and Prevention: A Pharmaceutical Approach to Medical Device Infections; John Wiley \& Sons: Hoboken, NJ, USA, 2010.

9. Trautner, B.W.; Lopez, A.I.; Kumar, A.; Siddiq, D.M.; Liao, K.S.; Li, Y.; Tweardy, D.J.; Cai, C. Nanoscale surface modification favors benign biofilm formation and impedes adherence by pathogens. Nanomed. Nanotechnol. Biol. Med. 2012, 8, 261-270. [CrossRef]

10. Stamm, W.E.; Hooton, T.M. Management of urinary tract infections in adults. N. Engl. J. Med. 1993, 329, 1328-1334. [CrossRef]

11. Buijssen, K.; Oosterhof, J.; Basil, L.; Waters, M.; Duits, M.; Busscher, H.; van der Mei, H.; van der Laan, B. Influence of surface roughness on silicone rubber voice prostheses on in vitro biofilm formation and clinical lifetime in laryngectomised patients. Clin. Otolaryngol. 2017, 42, 1235-1240. [CrossRef]

12. Gomes, L.C.; Mergulhão, F.J.M. SEM analysis of surface impact on biofilm antibiotic treatment. Scanning 2017, 2017. [CrossRef] [PubMed]

13. Teodósio, J.S.; Simões, M.; Melo, L.F.; Mergulhão, F.J.M. Flow cell hydrodynamics and their effects on E. coli biofilm formation under different nutrient conditions and turbulent flow. Biofouling 2011, 27, 1-11. [CrossRef] [PubMed]

14. Moreira, J.M.R.; Araújo, J.D.P.; Miranda, J.M.; Simões, M.; Melo, L.F.; Mergulhão, F.J.M. The effects of surface properties on Escherichia coli adhesion are modulated by shear stress. Colloids Surf. B Biointerfaces 2014, 123, 1-7. [CrossRef] [PubMed]

15. Nuzzo, R.G. Biomaterials: Stable antifouling surfaces. Nat. Mater. 2003, 2, 207-208. [CrossRef] 
16. Rodríguez-Emmenegger, C.; Brynda, E.; Riedel, T.; Houska, M.; Šubr, V.; Alles, A.B.; Hasan, E.; Gautrot, J.E.; Huck, W.T. Polymer brushes showing non-fouling in blood plasma challenge the currently accepted design of protein resistant surfaces. Macromol. Rapid Commun. 2011, 32, 952-957. [CrossRef]

17. Rodríguez-Emmenegger, C.; Houska, M.; Alles, A.B.; Brynda, E. Surfaces resistant to fouling from biological fluids: Towards bioactive surfaces for real applications. Macromol. Biosci. 2012, 12, 1413-1422. [CrossRef]

18. Ma, H.; Li, D.; Sheng, X.; Zhao, B.; Chilkoti, A. Protein-resistant polymer coatings on silicon oxide by surface-initiated atom transfer radical polymerization. Langmuir 2006, 22, 3751-3756. [CrossRef]

19. Gautrot, J.E.; Trappmann, B.; Oceguera-Yanez, F.; Connelly, J.; He, X.; Watt, F.M.; Huck, W.T. Exploiting the superior protein resistance of polymer brushes to control single cell adhesion and polarisation at the micron scale. Biomaterials 2010, 31, 5030-5041. [CrossRef]

20. Rodríguez-Emmenegger, C.; Decker, A.; Surman, F.; Preuss, C.M.; Sedláková, Z.; Zydziak, N.; Barner-Kowollik, C.; Schwartz, T.; Barner, L. Suppressing Pseudomonas aeruginosa adhesion via non-fouling polymer brushes. RSC Adv. 2014, 4, 64781-64790. [CrossRef]

21. De los Santos Pereira, A.; Sheikh, S.; Blaszykowski, C.; Pop-Georgievski, O.; Fedorov, K.; Thompson, M.; Rodriguez-Emmenegger, C. Antifouling polymer brushes displaying antithrombogenic surface properties. Biomacromolecules 2016, 17, 1179-1185. [CrossRef]

22. Lopez-Mila, B.; Alves, P.; Riedel, T.; Dittrich, B.; Mergulhão, F.J.M.; Rodríguez-Emmenegger, C. Effect of shear stress on the reduction of bacterial adhesion to antifouling polymers. Bioinspiration Biomimetics 2018. [CrossRef]

23. Zhao, C.; Zheng, J. Synthesis and characterization of poly(N-hydroxyethylacrylamide) for long-term antifouling ability. Biomacromolecules 2011, 12, 4071-4079. [CrossRef] [PubMed]

24. Tauhardt, L.; Pretzel, D.; Kempe, K.; Gottschaldt, M.; Pohlers, D.; Schubert, U.S. Zwitterionic poly(2-oxazoline)s as promising candidates for blood contacting applications. Polym. Chem. 2014, 5, 5751-5764. [CrossRef]

25. Surman, F.; Riedel, T.; Bruns, M.; Kostina, N.Y.; Sedláková, Z.; Rodríguez-Emmenegger, C. Polymer brushes interfacing blood as a route toward high performance blood contacting devices. Macromol. Biosci. 2015, 15, 636-646. [CrossRef] [PubMed]

26. Rodríguez Emmenegger, C.; Brynda, E.; Riedel, T.; Sedlakova, Z.; Houska, M.; Alles, A.B. Interaction of blood plasma with antifouling surfaces. Langmuir 2009, 25, 6328-6333. [CrossRef]

27. Riedel, T.; Riedelová-Reicheltová, Z.; Májek, P.; Rodríguez-Emmenegger, C.; Houska, M.; Dyr, J.E.; Brynda, E. Complete identification of proteins responsible for human blood plasma fouling on poly(ethylene glycol)-based surfaces. Langmuir 2013, 29, 3388-3397. [CrossRef]

28. Tischer, T.; Rodríguez-Emmenegger, C.; Trouillet, V.; Welle, A.; Schueler, V.; Mueller, J.O.; Goldmann, A.S.; Brynda, E.; Barner-Kowollik, C. Photo-patterning of non-fouling polymers and biomolecules on paper. Adv. Mater. 2014, 26, 4087-4092. [CrossRef]

29. Rodríguez-Emmenegger, C.; Janel, S.; de los Santos Pereira, A.; Bruns, M.; Lafont, F. Quantifying bacterial adhesion on antifouling polymer brushes via single-cell force spectroscopy. Polym. Chem. 2015, 6, 5740-5751. [CrossRef]

30. Donlan, R.M. Biofilms: Microbial life on surfaces. Emerg. Infect. Dis. 2002, 8, 881. [CrossRef]

31. Horn, H.; Reiff, H.; Morgenroth, E. Simulation of growth and detachment in biofilm systems under defined hydrodynamic conditions. Biotechnol. Bioeng. 2003, 81, 607-617. [CrossRef]

32. Azeredo, J.; Azevedo, N.F.; Briandet, R.; Cerca, N.; Coenye, T.; Costa, A.R.; Desvaux, M.; Di Bonaventura, G.; Hébraud, M.; Jaglic, Z. Critical review on biofilm methods. Critical Rev. Microbiol. 2017, 43, 313-351. [CrossRef] [PubMed]

33. Moreira, J.M.R.; Ponmozhi, J.; Campos, J.; Miranda, J.M.; Mergulhão, F.J.M. Micro-and macro-flow systems to study Escherichia coli adhesion to biomedical materials. Chem. Eng. Sci. 2015, 126, 440-445. [CrossRef]

34. Gomes, L.C.; Moreira, J.M.R.; Araújo, J.D.P.; Mergulhão, F.J.M. Surface conditioning with Escherichia coli cell wall components can reduce biofilm formation by decreasing initial adhesion. AIMS Microbiol. 2017, 24, 25. [CrossRef] [PubMed]

35. Mosayyebi, A.; Lange, D.; Yann Yue, Q.; Somani, B.; Zhang, X.; Manes, C.; Carugo, D. Reducing deposition of encrustation in ureteric stents by changing the stent architecture: A microfluidic-based investigation. Biomicrofluidics 2019, 13, 014101. [CrossRef] [PubMed] 
36. Mosayyebi, A.; Yue, Q.Y.; Somani, B.K.; Zhang, X.; Manes, C.; Carugo, D. Particle accumulation in ureteral stents is governed by fluid dynamics: In vitro study using a "stent-on-chip" model. J. Endourol. 2018, 32, 639-646. [CrossRef]

37. Stewart, P.S. Biophysics of biofilm infection. Pathog. Dis. 2014, 70, 212-218. [CrossRef]

38. Nauman, E.A.; Ott, C.M.; Sander, E.; Tucker, D.L.; Pierson, D.; Wilson, J.W.; Nickerson, C.A. Novel quantitative biosystem for modeling physiological fluid shear stress on cells. Appl. Environ. Microbiol. 2007, 73, 699-705. [CrossRef]

39. Rodesney, C.A.; Roman, B.; Dhamani, N.; Cooley, B.J.; Touhami, A.; Gordon, V.D. Mechanosensing of shear by Pseudomonas aeruginosa leads to increased levels of the cyclic-di-GMP signal initiating biofilm development. Proc. Natl. Acad. Sci. USA 2017, 114, 5906-5911. [CrossRef]

40. Gomes, L.C.; Moreira, J.M.R.; Teodósio, J.S.; Araújo, J.D.P.; Miranda, J.; Simões, M.; Melo, L.F.; Mergulhão, F.J.M. 96-well microtiter plates for biofouling simulation in biomedical settings. Biofouling 2014, 30, 535-546. [CrossRef]

41. Shah, K.J.; Cherabuddi, K.; Shultz, J.; Borgert, S.; Ramphal, R.; Klinker, K.P. Ampicillin for the treatment of complicated urinary tract infections caused by vancomycin resistant Enterococcus spp (VRE): A single-center university hospital experience. Int. J. Antimicrob. Agents 2017. [CrossRef]

42. Halperin, A.; Fragneto, G.; Schollier, A.; Sferrazza, M. Primary versus ternary adsorption of proteins onto PEG brushes. Langmuir 2007, 23, 10603-10617. [CrossRef] [PubMed]

43. Jeon, S.; Lee, J.; Andrade, J.; De Gennes, P. Protein-Surface interactions in the presence of polyethylene oxide: I. Simplified theory. J. Colloid Interface Sci. 1991, 142, 149-158. [CrossRef]

44. Sigal, G.B.; Mrksich, M.; Whitesides, G.M. Effect of surface wettability on the adsorption of proteins and detergents. J. Am. Chem. Soc. 1998, 120, 3464-3473. [CrossRef]

45. Li, J.; Kleintschek, T.; Rieder, A.; Cheng, Y.; Baumbach, T.; Obst, U.; Schwartz, T.; Levkin, P.A. Hydrophobic liquid-infused porous polymer surfaces for antibacterial applications. ACS Appl. Mater. Interfaces 2013, 5, 6704-6711. [CrossRef] [PubMed]

46. Mukherjee, J.; Karunakaran, E.; Biggs, C.A. Using a multi-faceted approach to determine the changes in bacterial cell surface properties influenced by a biofilm lifestyle. Biofouling 2012, 28, 1-14. [CrossRef]

47. Vila, J.; Sáez-López, E.; Johnson, J.; Römling, U.; Dobrindt, U.; Cantón, R.; Giske, C.; Naas, T.; Carattoli, A.; Martínez-Medina, M. Escherichia coli: An old friend with new tidings. FEMS Microbiol. Rev. 2016, 40, 437-463. [CrossRef]

48. Gomes, L.C.; Silva, L.; Simões, M.; Melo, L.F.; Mergulhão, F.J.M. Escherichia coli adhesion, biofilm development and antibiotic susceptibility on biomedical materials. J. Biomed. Mater. Res. Part A 2015, 103, 1414-1423. [CrossRef]

49. Alves, P.; Gomes, L.C.; Vorobii, M.; Rodríguez-Emmenegger, C.; Mergulhão, F.J.M. The potential advantages of using a poly(HPMA) brush in urinary catheters: Effects on biofilm cells and architecture. Colloids Surf. B Biointerfaces 2020, 191, 110976. [CrossRef]

50. Yao, Z.; Kahne, D.; Kishony, R. Distinct single-cell morphological dynamics under $\beta$-lactam antibiotics. Mol. Cell 2012, 48, 705-712. [CrossRef]

51. Martinez, O.V.; Gratzner, H.G.; Malinin, T.I.; Ingram, M. The effect of some $\beta$-lactam antibiotics on Escherichia coli studied by flow cytometry. Cytom. J. Int. Soc. Anal. Cytol. 1982, 3, 129-133. [CrossRef]

52. Ionescu, M.; Belkin, S. Overproduction of exopolysaccharides by an Escherichia coli K-12 rpoS mutant in response to osmotic stress. Appl. Environ. Microbiol. 2009, 75, 483-492. [CrossRef] [PubMed]

53. Hengge-Aronis, R.; Lange, R.; Henneberg, N.; Fischer, D. Osmotic regulation of rpoS-dependent genes in Escherichia coli. J. Bacteriol. 1993, 175, 259-265. [CrossRef] [PubMed]

54. Weber, H.; Polen, T.; Heuveling, J.; Wendisch, V.F.; Hengge, R. Genome-wide analysis of the general stress response network in Escherichia coli: oS-dependent genes, promoters, and sigma factor selectivity. J. Bacteriol. 2005, 187, 1591-1603. [CrossRef] [PubMed]

55. Dale, J.L.; Nilson, J.L.; Barnes, A.M.T.; Dunny, G.M. Restructuring of Enterococcus faecalis biofilm architecture in response to antibiotic-induced stress. NPJ Biofilms Microbiomes 2017, 3, 15. [CrossRef] [PubMed]

56. Uzoechi, S.C.; Abu-Lail, N.I. The Effects of $\beta$-Lactam Antibiotics on Surface Modifications of Multidrug-Resistant Escherichia coli: A Multiscale Approach. Microsc. Microanal. 2019, 25, 135-150. [CrossRef] [PubMed] 
57. Brooks, T.; Keevil, C. A simple artificial urine for the growth of urinary pathogens. Letters in Applied Microbiology 1997, 24, 203-206. [CrossRef]

58. Vagos, M.R.; Moreira, J.M.R.; Soares, O.S.G.P.; Pereira, M.F.R.; Mergulhão, F.J.M. Incorporation of carbon nanotubes in polydimethylsiloxane to control Escherichia coli adhesion. Polym. Compos. 2019, 40, E1697-E1704. [CrossRef]

59. Velraeds, M.M.; van de Belt-Gritter, B.; van der Mei, H.; Reid, G.; Busscher, H. Interference in initial adhesion of uropathogenic bacteria and yeasts to silicone rubber by a Lactobacillus acidophilus biosurfactant. J. Med. Microbiol. 1998, 47, 1081-1085. [CrossRef]

60. Barbosa, J.; Cuppini, M.; Flach, J.; Steffens, C.; Cansian, R.L.; Toniazzo, G. Removal of Escherichia coli in boning knives with different sanitizers. LWT Food Sci. Technol. 2016, 71, 309-315. [CrossRef]

61. Winkelströter, L.K.; Gomes, B.C.; Thomaz, M.R.S.; Souza, V.M.; De Martinis, E.C.P. Lactobacillus sakei 1 and its bacteriocin influence adhesion of Listeria monocytogenes on stainless steel surface. Food Control 2011, 22, 1404-1407. [CrossRef]

62. Romeu, M.J.; Alves, P.; Morais, J.; Miranda, J.M.; de Jong, E.D.; Sjollema, J.; Ramos, V.; Vasconcelos, V.; Mergulhão, F.J.M. Biofilm formation behaviour of marine filamentous cyanobacterial strains in controlled hydrodynamic conditions. Environ. Microbiol. 2019, 21, 4411-4424. [CrossRef] [PubMed]

63. Simões, M.; Pereira, M.O.; Vieira, M. The role of hydrodynamic stress on the phenotypic characteristics of single and binary biofilms of Pseudomonas fluorescens. Water Sci. Technol. 2007, 55, 437-445. [CrossRef] [PubMed]

(C) 2020 by the authors. Licensee MDPI, Basel, Switzerland. This article is an open access article distributed under the terms and conditions of the Creative Commons Attribution (CC BY) license (http://creativecommons.org/licenses/by/4.0/). 